\title{
Particulate Versus Non-Particulate Bulking Agents In The Treatment Of Stress Urinary Incontinence
}

This article was published in the following Dove Press journal:

Research and Reports in Urology

\author{
Christopher Chapple (D) \\ Roger Dmochowski \\ 'Department of Urology, Royal \\ Hallamshire Hospital, Sheffield, UK; \\ ${ }^{2}$ Department of Urology, Vanderbilt \\ University Medical Center, Nashville, \\ TN, USA
}

\begin{abstract}
Stress urinary incontinence (SUI) has been treated surgically with the midurethral sling but in recent years, this option has come under scrutiny and the risk-benefit balance continues to be reviewed. The low-risk alternative for women with uncomplicated SUI is the bulking agent, which aims to achieve continence through coaptation of the urethra. Two classes of bulking agents can be identified: those made from solid microparticles in an absorbable liquid or gel carrier (particulate agents) and those comprising a homogenous gel (non-particulates) that resists absorption. Polydimethylsiloxane ${ }^{\circledR}$, carbon-coated zirconium oxide $^{(}$, calcium hydroxyapatite $\left.{ }^{(}\right)$and polyacrylate polyalcohol copolymer $\left.{ }^{(}\right)$are currently marketed particulate agents. With the exception of calcium hydroxyapatite, the particles are non-degradable. Each agent achieves its long-term bulking effect through reactive changes around the persisting particles while the carrier volume is lost. Bulkamid ${ }^{\circledR}$ is a non-particulate agent with the bulking effect resulting from the volume of gel injected. The lasting network of fine fibers formed by the host tissue anchors the gel in situ. Foreign-body granulomas, erosion and migration/material extrusion and loss of bulk have been observed in connection with the particle-based products. Bulkamid may be mechanistically less liable to these events; however, there are minimal data directly comparing the two types of bulking agent. The question of durability is inevitable based on their differing modes of action.
\end{abstract}

Keywords: stress urinary incontinence, bulking agents, safety, particulate, non-particulate

\section{Introduction}

Stress urinary incontinence (SUI) is defined as the "involuntary loss of urine on effort, physical exertion, or on sneezing or coughing". 'The European Association Guidelines (EAU) on Urinary Incontinence in Adults recommends as first-line treatment of SUI the use of non-surgical therapies, such as simple clinical interventions, lifestyle interventions and behavioral and physical therapies, as they are associated with the least risk. $^{2}$ Surgical options for women with uncomplicated SUI, i.e., those with no history of previous surgery, no neurogenic lower urinary tract dysfunction, include the midurethral sling (MUS). The use of non-absorbable mesh for MUS has come under scrutiny in many countries and the risk-benefit balance continues to be reviewed. For example, guidance from NICE has recommended that surgeons offering a synthetic MUS should use those devices and procedures that are associated with a high level of safety and efficacy. ${ }^{3}$ The surgeon should be trained for the specific device used and only devices manufactured from type 1 macroporous polypropylene tape intended for this use are acceptable. The tape or mesh should also be colored for high visibility to assist insertion and revision. A more recent review from Scotland of the use, safety and efficacy of transvaginal mesh implants for the treatment of SUI
Correspondence: Christopher Chapple Department of Urology, Royal

Hallamshire Hospital, Glossop Road,

Sheffield SIO 2JF, UK

Tel +44 II 4 27I 3048

$\mathrm{Fax}+44$ II4 279784 I

Email c.r.chapple@shef.ac.uk
Research and Reports in Urology 2019:1 I 299-310

299

submit your manuscript in $\square$ 
reported that such implants could be supported on a case by case basis but actions are required to ensure good and safe patient care. ${ }^{4}$ One of the recommendations of the report was that women must be offered all appropriate treatments (mesh and non-mesh) as well as the information to make informed choices. Management of patients must follow agreed care pathways with emphasis on the importance of multidisciplinary assessment. In 2018, the US Food and Drugs Administration provided recommendations for health care providers in regard to the use of mesh procedures for SUI. ${ }^{5}$ Providers should be fully trained in the procedure and be vigilant for adverse events (AEs) such as erosion and for peri-operative complications such as bladder perforations. The patient should be fully informed of her treatment options for SUI, the details of the sling implant procedure and the associated complications.

In view of the recent adverse reporting on the mesh sling procedures, there has been renewed interest in the role of bulking agents and in gaining a better understanding of the materials and their mode of action. The EAU guidelines recommend bulking agents in the treatment of uncomplicated SUI for those women who request a low-risk procedure, with the understanding that repeat injections are likely and that long-term durability is not established. ${ }^{2}$ The American Association of Urology guidelines list bulking agents as a treatment option for women with SUI who wish to avoid more invasive surgical management or who are concerned with the lengthier recovery time after surgery or who experience insufficient improvement following a previous antiincontinence procedure. ${ }^{6}$ Patients should be counselled that repeat procedures may be required. There are a number of bulking agents that are currently in use and the major distinction is between particulate and non-particulate materials. This review will focus on their different modes of action with a focus on safety and durability.

\section{Mode Of Action}

Urethral bulking agents aim to treat SUI through improved coaptation of the urethra during the storage phase of the micturition cycle and where abdominal pressure is increased. Urethral resistance is increased at rest through this mechanism but the theoretic risk is that as it is increasing bladder outlet resistance then micturition could be impeded, although this is uncommon. The two most common approaches for injection of bulking materials are periurethral and transurethral, the target being the submucosa in the proximal or midurethra (Figure 1).
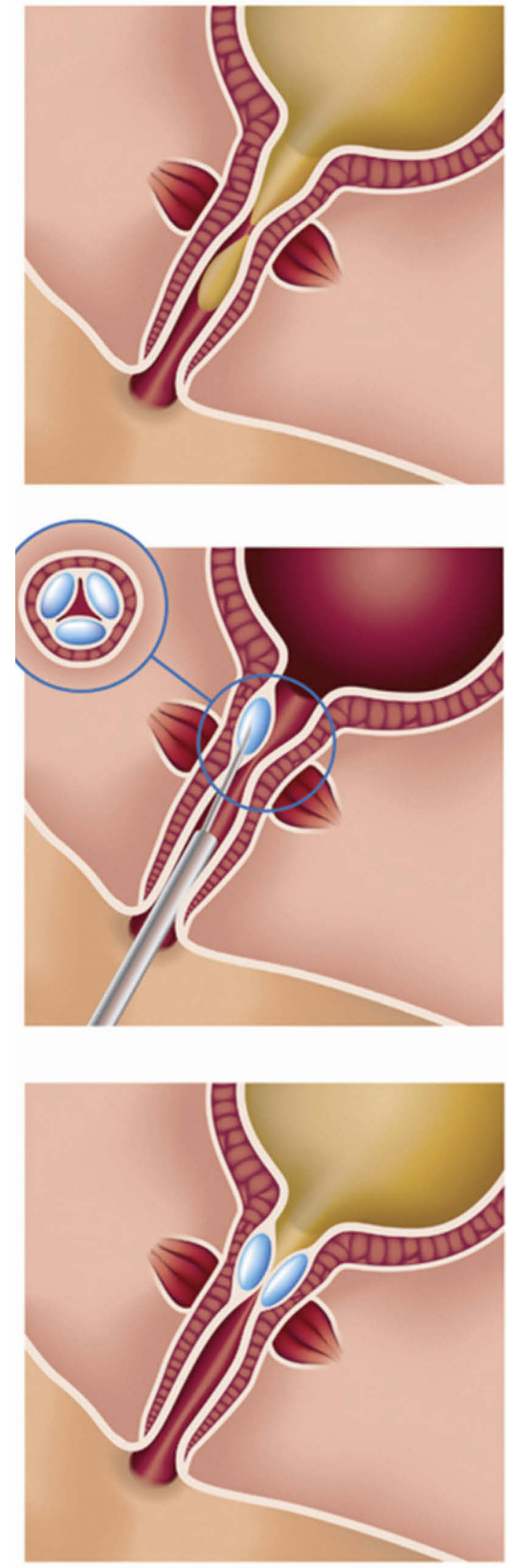

Figure I Peri-urethral injection of a bulking agent resulting in coaptation of the urethra. 
The ideal urethral bulking agent should be non-immunogenic and biocompatible, leading to minimal inflammatory and fibrotic response. ${ }^{7}$ There are primarily two classes of bulking agents: those made from solid microparticles in an absorbable liquid or gel carrier (particulate agents) and those comprising a homogenous gel (non-particulates) that resists absorption.

The two types of bulking agent have different modes of action and achieve their effect of urethral coaptation in different ways. In the case of the particulate bulking agents, their durable effect is due to their ability to induce a foreignbody reaction around the particles resulting in fibrosis formation (capsule) that provides the long-term cushion effect. ${ }^{8}$ The particles that make up the agent should be of sufficient size to prevent migration away from the site of injection (diameter $>80 \mu \mathrm{m}$ ) and of sufficient durability to maintain their effect over time. ${ }^{7}$ With this type of bulking agent, coaptation is dependent on the patient's tissue response to the microparticles and the subsequent bulking produced is a combination of the implanted material and the body's own collagen. ${ }^{9,10}$ Currently marketed particulate bulking agents are: polydimethylsiloxane ${ }^{\circledR}$ (Uroplasty Ltd, Reading, Berkshire, UK), carbon-coated zirconium oxide ${ }^{\circledR}$ (Carbon Medical Technologies, Saint Paul, Minnesota, USA), calcium hydroxyapatite ${ }^{\circledR}$ (Boston Scientific, Marlborough, Massachusetts, USA) (Figure 2) and polyacrylate polyalcohol copolymer $^{\circledR}$ (Promedon, Córdoba, Argentina). Polydimethylsiloxane comprises polydimethylsiloxane irregularly shaped fragments with a median size $110 \mu \mathrm{m}$ suspended in polyvinylpyrrolidone (PVP) carrier gel. The PVP carrier gel dissipates leaving behind the particles, which are non-degradable. ${ }^{10-12}$ carbon-coated zirconium oxide consists of carbon-coated zirconium oxide beads sized 251-300 $\mu \mathrm{m}$ suspended in a water-based carrier gel containing $2.8 \%$ betaglucan; the microspheres are non-degradable and the carrier dissipates. ${ }^{9,13}$ The third agent, calcium hydroxyapatite, is comprised of calcium hydroxylapatite microspheres sized $75-125 \mu \mathrm{m}$ in an aqueous carrier gel composed of sodium carboxymethylcellulose. The gel carrier degrades over several months, resulting in the growth of tissue around the particles; the beads are slowly degradable. ${ }^{14,15}$ polyacrylate polyalcohol copolymer is a polyacrylate polyalcohol copolymer with particles of average diameter of $300 \mu \mathrm{m}$ hydrated in a $40 \%$ glycerol solution. ${ }^{16}$ The particles increase the tissue volume to generate a minimum fibrotic growth around them of $70 \mu \mathrm{m} .^{17}$

In summary, in all of these approved agents the final bulking is achieved by the reactive changes around the

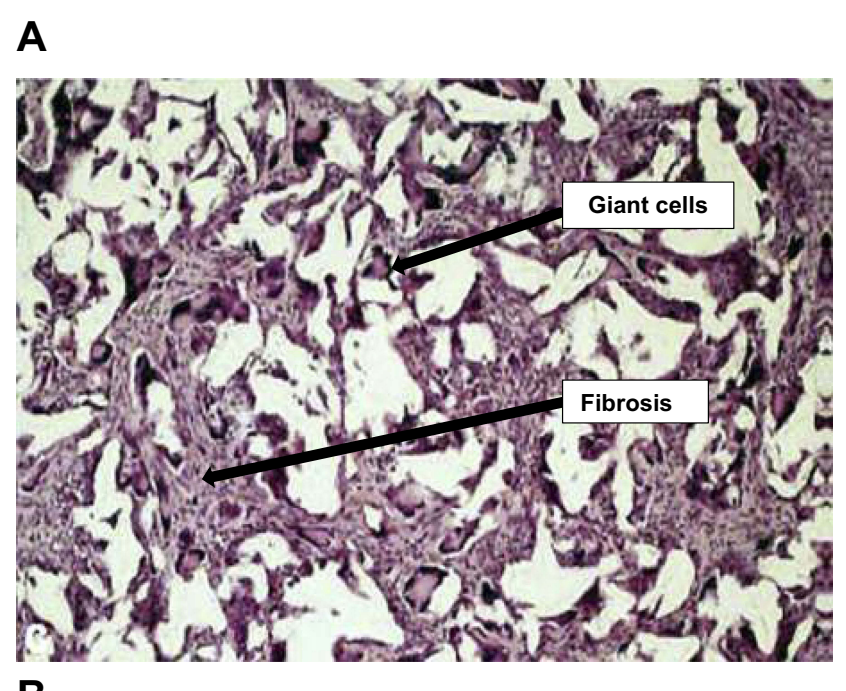

B

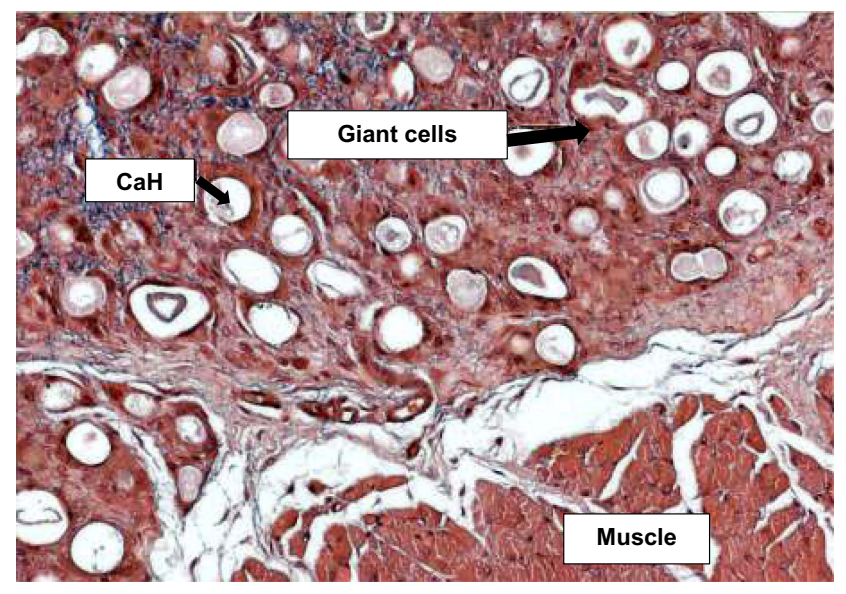

Figure 2 Urethral tissue interaction with the particulate bulking agents. (A) A highpower view to show the florid foreign-body type inflammatory reaction, with interparticle giant cells and fibrosis $(\mathrm{H \& E} \times 60) ;^{50}(\mathrm{~B})$ transverse histological section of the vocal fold injected calcium hydroxyapatite $(\mathrm{CaH})$ after 3 weeks of the procedure. Observe multinucleated giant cells involving the injected material $(\times 400)$. Reproduced from Vasconcelos SJ, Leão RA, Bernardino-Araújo S, Lira MM, Tsuji DH. Effect of sugarcane biopolymer in vocal fold of rabbits. Comparative study with calcium hydroxyapatite. Acta Cir Bras. 2015;30(3):186-193. ${ }^{51}$

persisting particles. An independent Scottish review on the use, safety and efficacy of transvaginal mesh implants in the treatment of SUI and pelvic organ prolapse in women also evaluated the use of bulking agents in SUI. ${ }^{4}$ The time period under review was from 1997 through 2014 and the key bulking agents in use in the 670 procedures evaluated were polydimethylsiloxane and Zuidex ${ }^{\circledR} /$ Deflux. ${ }^{\circledR}$ The report compared outcomes with the differing mesh procedures and bulking agents. Results were reported as the percentage increase or decrease in risk compared with open colposuspension and showed a disappointing number of readmissions for treatment within 5 years with the bulking agents (Figure 3).

There is a single non-particulate type of bulking agent currently marketed, Bulkamid $^{\mathbb{B}}$ (Contura International A/ 

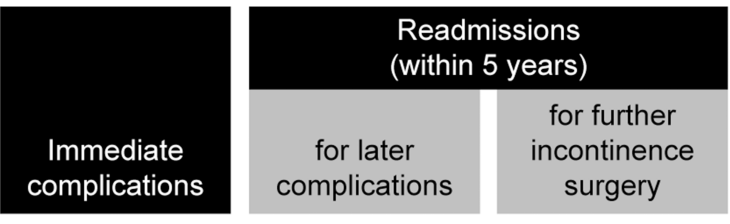

Percentage increase or decrease in risk compared with that seen

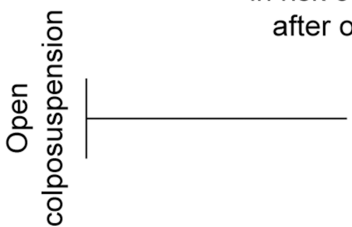

Compared

with this

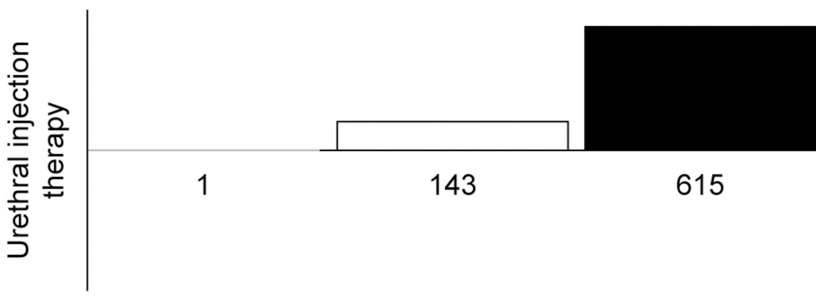

Figure 3 Percentage increase in risk compared with open colposuspension for readmission within 5 years for later complications or further treatment following an initial treatment with a bulking agent for stress urinary incontinence. Adapted from: Scottish Independent Review of the use, safety and efficacy of transvaginal mesh implants in the treatment of stress urinary incontinence and pelvic organ prolapse in women: March 2017. Reproduced from Scottish independent review of the use, safety and efficacy of transvaginal mesh implants in the treatment of stress urinary incontinence and pelvic organ prolapse in women: final report March; 2017. Available from: https://www2.gov.scot/Resource/005I/005I5856.pdf. Accessed April, 2019. Contains public sector information licensed under the Open Government Licence v3.0. ${ }^{4}$

$\mathrm{S}$, Denmark) is comprised of polyacrylamide hydrogel (PAHG; $2.5 \%$ polyacrylamide and $97.5 \%$ water) and is non-biodegradable. ${ }^{18}$ The bulking effect is obtained from the volume of the hydrogel injected and host cells enter the hydrogel and form a lasting network of fine fibers, which anchor the gel in situ (Figure 4). ${ }^{19}$ The aqueous part of the gel is loosely bound to the amide groups of the polymer backbone, and water molecules are constantly exchanged with water molecules of the surrounding tissue. ${ }^{20}$ Normal tissue constituents pass through the gel, allowing free exchange of nutrients and waste products with the surrounding tissue matrix. It is hoped that this agent will be safer and hence more effective than existing prior products in the market as noted above.

\section{Safety}

A range of AEs are possible with all bulking agents due to the procedure and the agent. However, certain AEs are specific to the type of agent with foreign-body granulomas, erosion and migration/material extrusion observed in connection with the particle-based products.

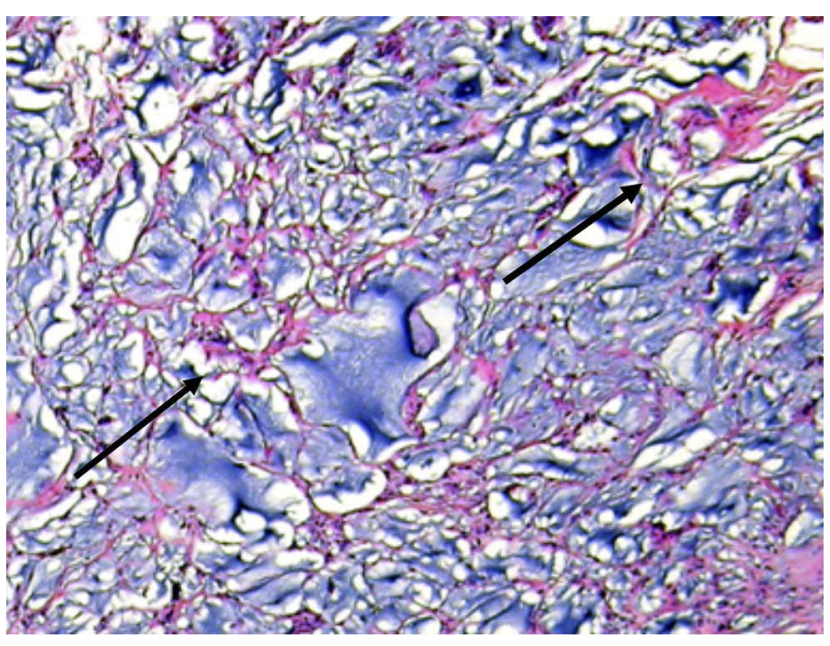

Figure 4 Histological photo of Bulkamid ${ }^{\circledR}$ traversed by a fine network at 14 months consisting of strands of fibrous tissue containing fibrous cells, blood vessels and a few macrophages (arrows), H\&E $\times 600$.

\section{Particulate Bulking Agents \\ Polydimethylsiloxane}

The importance of polydimethylsiloxane particle size in regard to migration was evidenced in animal study reported by Henley et al. ${ }^{12}$ In this histologic study, 13 female dogs received periurethral injection with a paste comprising particles either with a median diameter of $73 \mu \mathrm{m}$ or with one of 110 $\mu \mathrm{m}$. Histologic analysis of dogs injected with the smaller particle showed significant dissipation of injected material at 9 months, including to sites in the lung, lymph nodes, kidney and brain. In contrast, the dogs injected with the larger particle revealed a well-encapsulated fibrous sheath and no local migration; distant migration to the lung was observed in one animal where the particle size was $65 \mu \mathrm{m}$. Ghonheim et $\mathrm{al}^{21}$ have reported 12-month data in a comparative study of polydimethylsiloxane and a collagen-based bulking agent Contigen $^{\circledR}$. In the 122 patients who received polydimethylsiloxane, the most common $\mathrm{AE}$ reported was urinary tract infection (UTI) in 29 (23.8\%) patients, followed by dysuria urgency in 11 (9.0\%) patients each (Table 1). A 12-month study conducted by ter Meulen et $\mathrm{al}^{22}$ compared polydimethylsiloxane $(n=24)$ with pelvic floor exercises $(n=21)$. The most common AE was urinary retention reported in 19 (73.1\%) patients (Table 1). Of note, implant leakage occurred in two (7.7\%) patients. Retention and dysuria lasted 1 to 2 days except for one patient who had persistent retention due to de novo prolapse of the anterior vagina wall. Maher et $\mathrm{al}^{23}$ conducted a comparative study of polydimethylsiloxane $(n=23)$ versus pubovaginal sling $(\mathrm{n}=22)$ with 12-month outcome in 22 patients in both groups. Following injection with 
Table I Adverse Event (AE) Reporting Following Injection With A Particulate Bulking Agent

\begin{tabular}{|c|c|c|c|c|c|c|c|}
\hline \multirow[t]{2}{*}{ AE } & \multicolumn{4}{|c|}{ Polydimethylsiloxane $^{\circledR}$} & \multirow{2}{*}{$\begin{array}{l}\text { Calcium } \\
\text { Hydroxyapatite }^{\circledR}\end{array}$} & \multirow{2}{*}{ 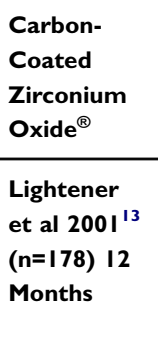 } & \multirow{2}{*}{$\begin{array}{l}\text { Polyacrylate } \\
\text { Polyalcohol } \\
\text { Copolymer }^{\circledR} \\
\text { Zangone } \\
\text { et al } 2012^{16} \\
(n=38) 60 \\
\text { Months }\end{array}$} \\
\hline & $\begin{array}{l}\text { Ghonheim } \\
\text { et } \mathrm{al}^{\mathrm{b}} \\
2009^{21} \\
(\mathrm{n}=122) \\
12 \text { Months }\end{array}$ & $\begin{array}{l}\text { ter Meulen } \\
\text { et } \text { al }^{\mathrm{a}} 2009^{22} \\
(\mathrm{n}=24) \\
12 \text { Months }\end{array}$ & $\begin{array}{l}\text { Maher et al } \\
2005^{23} \\
(n=23) \\
12 \text { Months }\end{array}$ & $\begin{array}{l}\text { Ghoniem } \\
\text { et al }\left.\right|^{c, d} \\
2013^{\prime \prime} \\
(n=958)\end{array}$ & & & \\
\hline UTI & $29(23.8 \%)$ & & $2(9.1 \%)$ & $3 \%$ & & & $3(7.9 \%)$ \\
\hline Dysuria & II (9.0\%) & $12(46.2 \%)$ & & $50 \%$ & & & $4(10.5 \%)$ \\
\hline Urgency & II (9.0\%) & & & & & $44(24.7 \%)$ & \\
\hline Frequency & $10(8.2 \%)$ & & & & & & \\
\hline Urinary retention & $8(6.6 \%)$ & 19 (73.1\%) & & $7 \%$ & $54(41 \%)$ & $30(16.9 \%)$ & 7 (I8.4\%) \\
\hline Hesitancy & $6(4.9 \%)$ & & & & & & \\
\hline Urge incontinence & $6(4.9 \%)$ & & & $7 \%$ & $7(5.7 \%)$ & & $9(23.7)$ \\
\hline Slowed urine stream & $5(4.1 \%)$ & & & & & & \\
\hline Incomplete bladder emptying & $5(4.1 \%)$ & & & & & & \\
\hline Hematuria & $5(4.1 \%)$ & $2(7.7 \%)$ & & $45 \%$ & & & \\
\hline Implant site pain & $4(3.3 \%)$ & & & & & & \\
\hline Overactive bladder & $3(2.5 \%)$ & & & & & & \\
\hline Yeast infection & $3(2.5 \%)$ & & & & & & \\
\hline Bladder pain & $2(1.6 \%)$ & & & & & & \\
\hline Urine stream change & $2(1.6 \%)$ & & & & & & \\
\hline Increased/worsening nocturia & $2(1.6 \%)$ & & & & & & \\
\hline Urethral erosion & $2(1.6 \%)$ & & & & & & \\
\hline $\begin{array}{l}\text { Other (including headaches, } \\
\text { nausea) }\end{array}$ & $22(18.0 \%)$ & & & & & & \\
\hline Mild pain & & $2(7.7 \%)$ & & & & & \\
\hline Implant leakage & & $2(7.7 \%)$ & & & & & \\
\hline Voiding dysfunction & & & I (5\%) & & & & \\
\hline Vaginal erosion & & & & & $\mathrm{I}(0.8 \%)$ & & \\
\hline
\end{tabular}

Notes: ${ }^{a}$ As a percentage of injections administered; ${ }^{b}$ as a percentage of patients; ${ }^{c}$ includes studies by ter Meulen, Ghoneim and Maher. ${ }^{\mathrm{d}}$ Median values are shown. Abbreviation: UTI, urinary tract infection.

polydimethylsiloxane, five $(22.7 \%)$ required a top-up transurethral injection and two (9.1\%) incurred a UTI. A metaanalysis by Ghonheim and Miller ${ }^{11}$ was reported involving 23 patient cohorts $(\mathrm{n}=958)$ from 24 articles published from 1990 to 2010 on randomised controlled studies, prospective observational studies and retrospective studies of clinical practice. Median rates for AEs were: 3\% (IQR, 0-8), UTIs; 7\% (IQR, 5-15), temporary urinary retention; 7\% (IQR, 4-27), urge incontinence, 45\% (IQR, 8-64), transient hematuria; and $50 \%$ (IQR, 11-79), temporary dysuria. No reports were made for extrusion, migration, immune reaction, embolic phenomena, vascular occlusion or other serious AEs.

\section{Calcium Hydroxyapatite}

Mayer et $\mathrm{a}^{15}$ conducted a 12-month randomised controlled study involving calcium hydroxyapatite and bovine collagen 
in 296 women. The AEs reported in the 131 patients treated with calcium hydroxyapatite are listed in Table 1. Eleven patients demonstrated a serious $\mathrm{AE}$ and two of these were considered to be treatment-related (potentially technique). One involved vaginal wall erosion and the investigators suggested that this was likely due to prolonged local tissue pressure effects and not direct tissue toxicity of the agent; the patient subsequently underwent a suburethral sling procedure. The second patient had a dissection of the bulking material beneath the trigonal mucosa but no clinically significant ureteral obstruction; no intervention was needed.

A rare AE following bulking treatment for SUI is urethral prolapse and it has been hypothesized that the agent impacts on the support between the mucosa and muscle underlying it; laxity on the periurethral tissues may predispose to prolapse. ${ }^{24}$ Ko et $\mathrm{al}^{25}$ reported urethral prolapse in a woman treated with calcium hydroxyapatite for urinary incontinence 4 months after undergoing a distal urethrectomy. The prolapse occurred 1 month after treatment with the bulking agent. During the subsequent resection of the prolapse, crystalline material was observed extruding from the surgical site. Similarly, Lai et $\mathrm{al}^{26}$ presented a case study of a woman who had had two previous incontinence surgeries treated with calcium hydroxyapatite who developed urethral prolapse at 7 months post-injection. Local migration of calcium hydroxylapatite particles from the site of injection to the distal urethra was observed during surgical correction. The authors suggest that good injection technique is essential for treatment success particularly, as in the case of this patient, in those who have had previous urethral surgeries or in patients with a scarred/fixed urethra.

Palma et $\mathrm{al}^{27}$ reported a case of a granulomatous reaction leading to urethral prolapse at 3 months after treatment with calcium hydroxyapatite. Histopathological analysis showed a lymphomonocytic inflammatory response and a chronic granulomatous inflammatory response with giant cells and macrophages surrounding the injected particles. Inside the implant was a mild to moderate fibroblast reaction. Gafni-Kane et $\mathrm{al}^{28}$ presented two cases of foreign-body granuloma after injection of calcium hydroxyapatite. It was considered that in one patient the granuloma was as a result of the result of blockage of a periurethral duct by the calcium hydroxylapatite implant. Excision of the lesion resolved the patient pain and she subsequently underwent a second successful bulking treatment with the same agent. The second patient had previously undergone an unsuccessful MUS procedure for SUI. Three rounds of bulking injections were given over 2 months to achieve continence. Following the first treatment, the urothelium was described as "quite friable" and three ruptures of calcium hydroxylapatite into the urethra were noted with injection. At 19 months after the last injection, when a second sling procedure was being conducted for incontinence recurrence, a nodule containing calcium hydroxylapatite was detected making sling placement not feasible. Pathology revealed fibrous tissue with polarizable foreign material and associated multinucleated giant cells consistent with a foreign-body granuloma. The investigators suggest that periurethral rather than transurethral injection avoids the piercing of the urothelium and consequently reduces the risk of communication between the bulking agent and the urethral lumen.

\section{Carbon-Coated Zirconium Oxide ${ }^{\circledR}$}

Lightener et $\mathrm{al}^{13}$ conducted a 12-month randomised controlled trial comparing carbon-coated zirconium oxide and bovine collagen in 355 women. The AEs reported in the group of patients treated with carbon-coated zirconium oxide $(n=178)$ are shown in Table 1 . There was no evidence of particle migration reported. Ghoniem and Khater $^{29}$ reported a case of urethral prolapse in a patient with a history of bladder support procedures plus multiple carbon-coated zirconium oxide injections, which it was suggested might have disrupted the support between the urethral mucosa and the underlying submucosal tissue. The prolapsed part of the urethra was resected and fibrin glue injected in order to support the urethral mucosa. The patient remained continent with no further treatment given. Histopathology revealed transitional epithelium with submucosal inflammatory changes and carbon-coated zirconium oxide particles. Pannek et $\mathrm{al}^{30}$ reported a single case of particle migration following carbon-coated zirconium oxide injection in 13 women who had previously undergone at least one unsuccessful surgery for urinary incontinence. At 3 months, post-procedure carbon beads were identified in regional and distant lymph nodes. Madjar et $\mathrm{al}^{31}$ presented findings on periurethral abscess formation in four of 135 patients treated with carbon-coated zirconium oxide at 12 to 18 months post-injection; in one patient the mass measured $4 \mathrm{~cm}$. Symptoms included irritative voiding symptoms, pelvic pain and urinary incontinence. Cyst drainage revealed a cloudy white paste containing carboncoated zirconium oxide beads. Excision of the mass in one patient showed it to be a cyst lined by squamous epithelium focally infiltrated with neutrophils with adjacent fibrosis. Pseudoabscess formation in the anterior vaginal wall was reported in another case at 5 years after injection with carbon-coated zirconium oxide. ${ }^{32}$ At 1 year prior to treatment with the bulking agent, she had undergone an MUS 
procedure but incontinence symptoms persisted. Resection of the mass, which was shown to contain bulking material, reduced the patient's pelvic pain and dyspareunia; the patient remained continent.

\section{Polyacrylate Polyalcohol Copolymer}

Zangone et al published 60-month outcome data on 38 patients treated with polyacrylate polyalcohol copolymer. ${ }^{16}$ The most frequent AE was de novo urge incontinence $(n=9)$ followed by urinary retention $(n=7)$, dysuria $(n=4)$ and UTI $(n=3)$.

\section{Non-Particulate Agents Bulkamid}

Lose et al have reported two prospective 12-month studies on women treated with PAHG (Aquamid ${ }^{\circledR}$ ). The first study was a pilot study reported in 2006 and involved 25 women with 12-month follow-up available in $21 .{ }^{18}$ A total of 37 AEs were reported in 16 women and 24 of these were considered treatment-related (Table 2). At 12 months, the two cases of de novo urge incontinence had resolved spontaneously. Four women reported extravasation of PAHG from the urethra and recurrence of incontinence during the first month of follow-up. Some of the leakage was from the injection site and to overcome this the viscosity and cohesiveness of the PAHG was increased in a modified PAHG (Bulkamid) in addition to reducing the diameter of the injection needle. The second study involved 135 women with SUI and mixed incontinence and of these 59 experienced an AE after 12 months; 88 non-serious (57 patients) and eight serious (eight patients) AE. ${ }^{33}$ Of the 88 non-serious AEs, 30 were classified as possibly (19), or probably (11) related to the treatment (Table 2). Of the eight serious AE, two cases of UTI were classed as treatment-related. No PAHG-specific AEs were reported. A further 12-month prospective study was published in 2013 and included 82 patients. ${ }^{34}$ Twentyone $(25.6 \%)$ experienced an $\mathrm{AE}$ due to the procedure, the most common of which was UTI (Table 2). Sokol et al ${ }^{35}$ conducted a randomised 12-month comparative study of Bulkamid versus collagen gel (Contigen) in 345 women. A total of 381 AEs were reported in 136 women treated with Bulkamid and 81 AEs in 58 women were classed as procedure- or device-related (Table 2). One of the 18 serious AEs (transient hematuria) was classed as probably related to treatment with Bulkamid. Zivanovic et $\mathrm{al}^{36}$ conducted a 12-month observational study of Bulkamid treatment in 60 patients with recurrent SUI or mixed incontinence following one or more previous MUS procedures. The AEs reported up to 1,6 and 12 months are shown in Table 2. Persistent urge incontinence occurred in up to $20 \%$ of patients out to 20 months but no de novo cases were observed. Another 12-month study compared Bulkamid treatment in patients with severe SUI who had undergone radiotherapy to the pelvis for a gynecological condition $(\mathrm{n}=24)$ with those who had not undergone radiotherapy $(n=22){ }^{37}$ There was a low incidence of AEs reported in both groups, none of which were serious AEs (Table 2).

Longer term follow-up has been published by ToozsHobson et $\mathrm{al}^{38}$ involving 135 patients for SUI or mixed urinary incontinence. At 24-month follow-up, 16 non-serious AEs and four serious AEs were reported, none of which was thought to be related to the treatment. No cases of impaired bladder emptying based on postvoid residuals were reported. The summary of 3-year outcome in a study of 256 patients with SUI or mixed urinary incontinence by Pai and Al-Singary ${ }^{39}$ stated that one patient developed infection, abscess or allergic reaction at the site of the injection and one patient a UTI. At 8-year follow-up of 24 patients injected with Bulkamid, vaginal ultrasonography showed all patients had visible polyacrylamide hydrogel deposits. ${ }^{40}$ No local AEs were observed in the vaginal mucosa and no patient experienced dysuria or vaginal discharge or reported that the injected deposits were felt during intercourse or physical activity. One patient had experienced stranguria and seven recurrent cystitis. A single case of periurethral abscess was reported at 3 months following treatment with Bulkamid. ${ }^{41}$ The patient presented with urethral pain, frequency, urgency and voiding difficulties. At 4 years prior to bulking treatment, she had had a total vaginal mesh repair and later a vaginal hysterectomy and simultaneous transobturator tape insertion. Surgical drainage of the abscess was conducted vaginally, which resolved the pain but resulted in recurrence of incontinence. The authors suggest that the patient's history of previous surgeries and diabetes mellitus put her at increased risk of abscess formation.

A recent randomised, controlled study compared Bulkamid with tension-free vaginal tape in 224 women with SUI. ${ }^{42}$ The majority of peri-operative complications (hematoma, bladder perforation or urinary retention) and all repeat procedures due to complications were linked to transvaginal tape (TVT) procedures. Also erosions, pelvic/ implantation site pain and difficulty to empty the bladder at 1-year follow-up were associated only with TVT. 


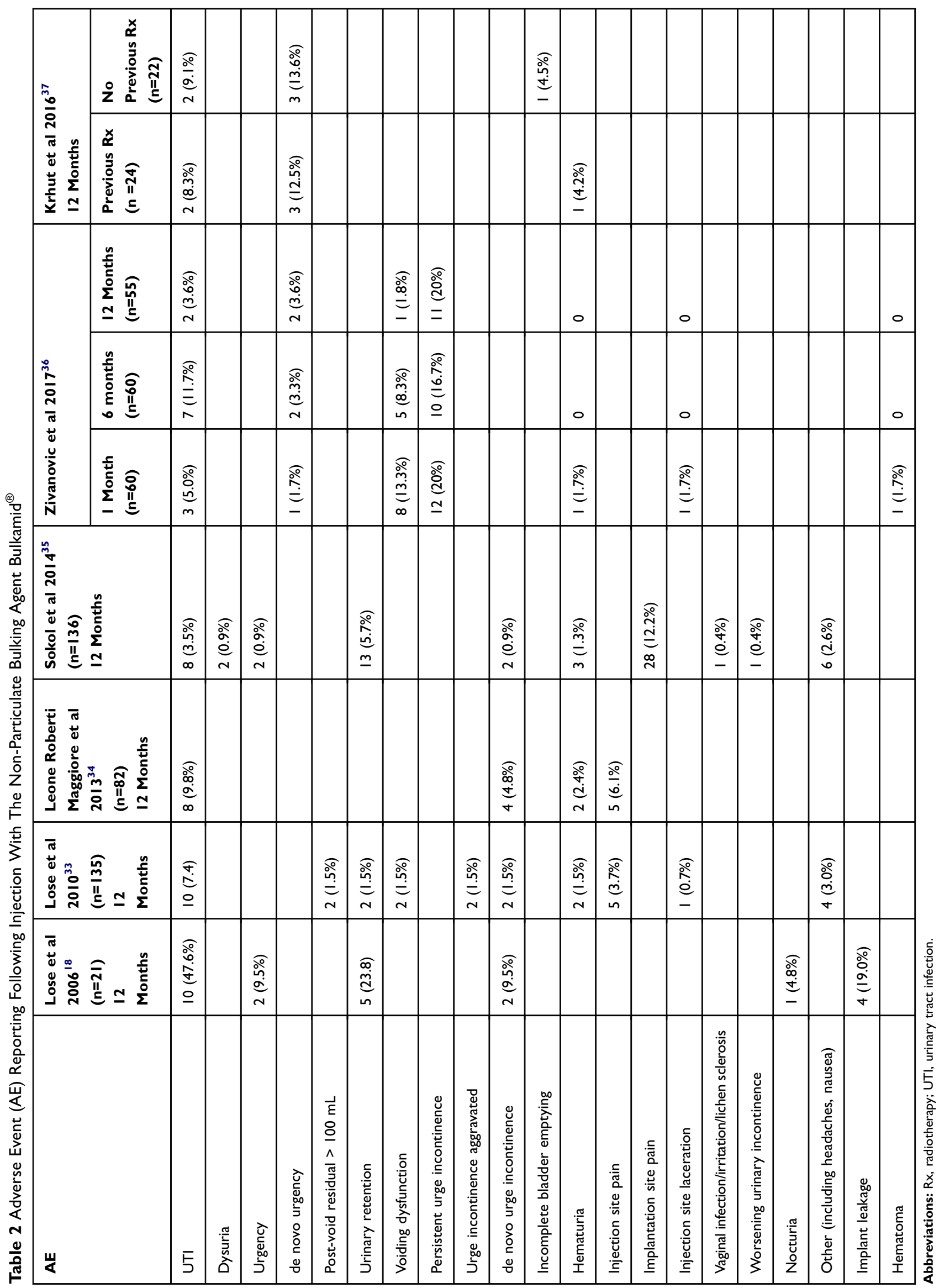




\section{Particulates And Non-Particulate Bulking Agents}

Islam et $\mathrm{al}^{43}$ conducted a meta-analysis of 1022 studies published between 1996 and 2014 involving 4326 patients treated with one of six bulking agents using reports that overlap with the information cited previously in this paper. Of the 1999 complications reported, 3.8\% were considered major (Clavien III) and required either incision and drainage or a more invasive procedure. The incidence of major complications for carbon-coated zirconium oxide was $9.4 \%$, calcium hydroxyapatite was $7.4 \%$ and Bulkamid was $0.8 \%$; no serious complications were reported for polydimethylsiloxane. A similar meta-analysis published by de Vries et al ${ }^{44}$ in 2018 evaluated eight urethral bulking agents and reported 2095 complications in 6462 treated patients in 79 studies. The number of complications ( $\%$ of patients treated) for the particulate bulking agents was: calcium hydroxyapatite, 64 (45\%); carbon-coated zirconium oxide, 80 (25\%); and polydimethylsiloxane, 620 (95\%). A total of 189 (18\%) of complications were recorded for Bulkamid. A total of 67 complications were classed as Clavien III complications and the reported incidence was: calcium hydroxyapatite, one; carbon-coated zirconium oxide, four; polydimethylsiloxane, zero; and Bulkamid, one.

\section{Discussion}

Historically a number of bulking agents have been studied for the treatment of SUI in women but several were discontinued due to safety concerns. Autologous fat harvested from the patient's abdominal wall washed and re-suspended in saline has been used but further development was halted due to rapid digestion and potential migration of the material. ${ }^{45}$ Contigen ${ }^{\circledR}$ (C.R. Bard, Covington, GA) comprises glutaraldehyde crosslinked bovine collagen that is formed by cross-linking bovine dermal collagen with glutaraldehyde and dispersing it in phosphate-buffered physiological saline. Hypersensitivity skin reactions are possible and a skin test is required prior to use. Delayed skin reactions and arthralgia are potential late complications as well as more serious complications, such as pulmonary embolism and osteitis pubis. ${ }^{7}$ Production issues with the product led to it being discontinued in 2009 . Zuidex ${ }^{\circledR}$, a combination of a hydrophilic dextran polymer and a hyaluronic acid base, was withdrawn as a treatment for SUI due to safety concerns of abscess and pseudocyst formation. ${ }^{46}$ The same compound is also marketed as Deflux $^{\circledR}$ and used primarily for vesicoureteral reflux in children. Polytetrafluorethylene (Polytef ${ }^{\mathrm{TM}}$ ) is a bulking agent made up of paste containing polytetrafluorethylene, glycerine and polysorbate. Clinical use of the agent was discontinued due to particle migration. ${ }^{7}$ Tegress ${ }^{\mathrm{TM}} / \mathrm{Uryx}^{\mathrm{TM}}$ (ethylene vinyl alcohol copolymer; C.R. Bard, Covington, GA, USA) use as a bulking agent in SUI was associated with serious complications and it was hypothesized that the high erosion rates were secondary to the chemical reaction that occurs during injection as the dimethylsulphoxide, the carrier in which the polymer is dispensed, is washed away. ${ }^{47}$ Tegress $^{\mathrm{TM}}$ was withdrawn from the USA market in 2007 due to safety concerns. Currently marketed is a solid implant, Urolastic ${ }^{\mathbb{R}}$, which consists of a vinyldimethyl terminated polydimethylsiloxane polymer, tetrapropoxysilane cross-linking agent, platinum vinyltetramethyl siloxane complex catalyst and titanium dioxide radiopacifying agent. ${ }^{48}$ The material polymerizes in situ to form an elastomer, changing from a liquid to a solid state to form a cuff effect around the urethra. ${ }^{48}$ Urolastic $^{\circledR}$ is associated with vaginal erosion rates of up to $21.5 \%$, many of which required implant excision. ${ }^{49}$

A number of AEs were reported that were common to all bulking agents and these included UTI, dysuria, urgency, urinary retention and hematuria. With the proviso that clinical data pertaining to one class cannot be transferrable to the other class and it is difficult to compare incidence rates across studies due to differences, for example, in patient inclusion and follow-up procedures, the frequency with which these AEs occurred does appear to differ with dysuria, urinary retention and urgency appeared more common with the particulate bulking agents compared with the non-particulate bulking agent while UTI was more commonly reported with the later.

The primary difference between the two types of bulking agent was the development following injection of the particulate bulking agent calcium hydroxyapatite of three cases of urethral prolapse which was associated lymphomonocytic inflammatory response and a chronic granulomatous inflammatory response in one patient. Two further cases of foreignbody granuloma were reported following calcium hydroxyapatite injection. Urethral prolapse has also been reported with carbon-coated zirconium oxide gain associated with inflammatory changes. Particle migration, pseudoabscess and cyst formation have been evidenced with carbon-coated zirconium oxide implantation. Of concern was the observation of pseudoabscess at 5 years post-implant, suggesting that continued patient monitoring should be conducted. Implant leakage was reported in four patients injected PAHG but subsequent remodeling of the injection needle and increased viscosity of the agent overcame this issue. 


\section{Conclusion}

Bulking agents should be differentiated into two classes based on their mode of action and whilst few head-to-head data exist, differential safety profiles are emerging. The question of the durability differences between the two types of bulking agent inevitably arises where one group of agents is dependent on the body's inflammatory reaction to form the bulking volume and the other is based on injected volume. Comparative clinical studies would be required to determine this.

\section{Acknowledgment}

Editorial support was provided by Medscimedia Ltd. and funded by Contura Ltd.

\section{Disclosure}

C Chapple has acted as a consultant/advisor for Ferring, Contura, Astellas Pharma, Bayer Schering Parma AG, Galvani Bioelectronics (GSK), Pierre Fabre, Symimetics, Taris Biomedical, and Urovant Sciences. He has acted as an author for Allergan publications and as a researcher in scientific studies for Ipsen and as a speaker for Pfizer. He has also received a grant from Astellas Pharma and personal fees from Astellas Pharma, Bayer Schering Parma AG, Pierre Fabre, Pfizer, Ferring, Galvani Bioelectronics (GSK), Taris Biomedical, and Urovant Sciences. R Dmochowski has acted as a consultant for Axonicx, Blue Wind, Contura and Viveve. The authors report no other conflicts of interest in this work.

\section{References}

1. Haylen BT, de Ridder D, Freeman RM, et al. An International Urogynecological Association (IUGA)/International Continence Society (ICS) joint report on the terminology for female pelvic floor dysfunction. Int Urogynecol J. 2010;21(1):5-26. doi:10.1007/s00192009-0976-9

2. Burkhard FC, Bosch JLHR, Cruz F, et al. EAU guidelines on urinary incontinence in adults. Available from: https:/uroweb.org/guideline/ urinary-incontinence. Accessed April, 2019.

3. Urinary incontinence in women: management. National Institute for Health and Care Excellence Clinical Guideline on Urinary Incontinence in Women: management, guideline CG171 November 2015. Available from: https://www.nice.org.uk/guidance/cg171/chapter/1 Recommendations\#surgical-approaches-for-sui-2. Accessed April, 2019.

4. Scottish independent review of the use, safety and efficacy of transvaginal mesh implants in the treatment of stress urinary incontinence and pelvic organ prolapse in women: final report March; 2017. Available from: https:// www2.gov.scot/Resource/0051/00515856.pdf. Accessed April, 2019.

5. The US Food \& Drug Administration Information for Health Care Providers for SUI. March 2018. Available from: https://www.fda.gov/ MedicalDevices/ProductsandMedicalProcedures/ImplantsandProsthetics/ UroGynSurgicalMesh/ucm345221.htm. Accessed April 2019.
6. Kobashi KC, Albo ME, Dmochowski RR, et al. AUA/SUFU Guideline; 2017. Available from: https://www.auanet.org/guidelines/stress-urinaryincontinence-(sui)-guideline\#x4490. Accessed May, 2019.

7. Kirchin V, Page T, Keegan PE, et al. Urethral injection therapy for urinary incontinence in women. Cochrane Database Syst Rev. 2017;7:CD003881. doi:10.1002/14651858.CD003881.pub4

8. Christensen LH. Host tissue interaction, fate, and risks of degradable and nondegradable gel fillers. Dermatol Surg. 2009;35 Suppl 2:16121619. doi:10.1111/j.1524-4725.2009.01338.x

9. Food and drug administration summary of safety and effectiveness data: carbon-coated zirconium oxide injectable bulking agent; 1999. Available from: https://www.accessdata.fda.gov/cdrh_docs/pdf/ P980053B.pdf. Accessed April, 2019.

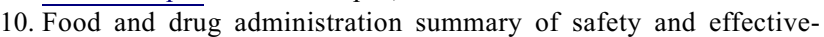
ness data: polydimethylsiloxane; 2006. Available from: https:// www.accessdata.fda.gov/cdrh_docs/pdf4/p040050b.pdf. Accessed April 2019.

11. Ghoniem GM, Miller CJ. A systematic review and meta-analysis of polydimethylsiloxane for treating female stress urinary incontinence. Int Urogynecol J. 2013;24(1):27-36. doi:10.1007/s00192-012-1825-9

12. Henly DR, Barrett DM, Weiland TL, O'Connor MK, Malizia AA, Wein AJ. Particulate silicone for use in periurethral injections: local tissue effects and search for migration. J Urol. 1995;153(6):2039-2043.

13. Lightner D, Calvosa C, Andersen R, et al. A new injectable bulking agent for treatment of stress urinary incontinence: results of a multicenter, randomized, controlled, double-blind study of carbon-coated zirconium oxide. Urology. 2001;58(1):12-15. doi:10.1016/s0090-4295(01)01148-7

14. Food and drug administration instructions for use: calcium hydroxyapatite, 2005. Available from: https://www.accessdata.fda.gov/ cdrh_docs/pdf4/P040047c.pdf. Accessed April, 2019.

15. Mayer RD, Dmochowski RR, Appell RA, et al. Multicenter prospective randomized 52-week trial of calcium hydroxylapatite versus bovine dermal collagen for treatment of stress urinary incontinence. Urology. 2007;69(5):876-880. doi:10.1016/j.urology.2007.01.050

16. Zangone MA, Olmedo T, Olea M. Transurethral bulking agent injection in female stress urinary incontinence: long term results using polyacrylate polyalcohol copolymer ${ }^{\circledR}$. Pelviperineology. 2012;31(3):92-95.

17. Promedon urosys product brochure. Available from: http://www.pro medon-urologypf.com/opsys, Accessed August 21, 2019.

18. Lose G, Mouritsen L, Nielsen JB. A new bulking agent (polyacrylamide hydrogel) for treating stress urinary incontinence in women. BJU Int. 2006;98(1):100-104. doi:10.1111/j.1464-410X.2006.06205.X

19. Christensen LH, Nielsen JB, Mouritsen L, Sørensen M, Lose G. Tissue integration of polyacrylamide hydrogel: an experimental study of periurethral, perivesical, and mammary gland tissue in the pig. Dermatol Surg. 2008;34 Suppl 1:S68-77. doi:10.1111/j.1524-4725.2008.34246.x

20. Brahm J, Lessel R, Ditlev S, Schmidt R. Flux of selected body fluid constituents and benzylpenicillin in polyacrylamide hydrogel (PAAG). $J$ Tissue Eng Regen Med. 2012;6(10):793-802. doi:10.1002/term.485

21. Ghoniem G, Corcos J, Comiter C, Bernhard P, Westney OL, Herschorn S. Cross-linked polydimethylsiloxane injection for female stress urinary incontinence: results of a multicenter, randomized, controlled, singleblind study. J Urol. 2009;181(1):204-210. doi:10.1016/j.juro.2008.09.032

22. ter Meulen PH, Berghmans LC, Nieman FH, van Kerrebroeck PE. Effects of polydimethylsiloxane implantation system for stress urinary incontinence and urethral hypermobility in women. Int Urogynecol J Pelvic Floor Dysfunct. 2009;20(2):177-183. doi:10.1007/s00192-008-0741-5

23. Maher CF, O'Reilly BA, Dwyer PL, Carey MP, Cornish A, Schluter P. Pubovaginal sling versus transurethral polydimethylsiloxane for stress urinary incontinence and intrinsic sphincter deficiency: a prospective randomised controlled trial. BJOG. 2005;112(6):797-801. doi:10.1111/j.1471-0528.2005.00547.x

24. Harris RL, Cundiff GW, Coates KW, Addison A, Bump RC. Urethral prolapse after collagen injection. Am J Obstet Gynecol. 1998;178 (3):614-615. doi:10.1016/s0002-9378(98)70450-8 
25. Ko EY, Williams BF, Petrou SP. Bulking agent induced early urethral prolapse after distal urethrectomy. Int Urogynecol J Pelvic Floor Dysfunct. 2007;18(12):1511-1513. doi:10.1007/s00192-007-0439-0

26. Lai HH, Hurtado EA, Appell RA. Large urethral prolapse formation after calcium hydroxylapatite (calcium hydroxyapatite) injection. Int Urogynecol J Pelvic Floor Dysfunct. 2008;19(9):1315-1317. doi:10.10 07/s00192-008-0604-0

27. Palma PC, Riccetto CL, Martins MH, et al. Massive prolapse of the urethral mucosa following periurethral injection of calcium hydroxylapatite for stress urinary incontinence. Int Urogynecol J Pelvic Floor Dysfunct. 2006;17(6):670-671. doi:10.1007/s00192-005-0038-x

28. Gafni-Kane A, Sand PK. Foreign-body granuloma after injection of calcium hydroxylapatite for type III stress urinary incontinence. Obstet Gynecol. 2011;118(2 Pt 2):418-421. doi:10.1097/ AOG.0b013e3182161953

29. Ghoniem GM, Khater U. Urethral prolapse after carbon-coated zirconium oxide injection. Int Urogynecol J Pelvic Floor Dysfunct. 2006;17(3):297-298. doi:10.1007/s00192-005-1336-Z

30. Pannek J, Brands FH, Senge T. Particle migration after transurethral injection of carbon coated beads for stress urinary incontinence. $J$ Urol. 2001;166:1350-1353.

31. Madjar S, Sharma AK, Waltzer WC, Frischer Z, Secrest CL. Periurethral mass formations following bulking agent injection for the treatment of urinary incontinence. J Urol. 2006;175(4):14081410. doi:10.1016/S0022-5347(05)00679-8

32. Berger MB, Morgan DM. Delayed presentation of pseudoabscess secondary to injection of pyrolytic carbon-coated beads bulking agent. Female Pelvic Med Reconstr Surg. 2012;18(5):303-305. doi:10.1097/SPV.0b013e318264c8e0

33. Lose G, Sørensen HC, Axelsen SM, Falconer C, Lobodasch K, Safwat T. An open multicenter study of polyacrylamide hydrogel (Bulkamid ${ }^{\mathbb{R}}$ ) for female stress and mixed urinary incontinence. Int Urogynecol J. 2010;21(12):1471-1477. doi:10.1007/s00192-010-1214-1

34. Leone Roberti Maggiore U, Alessandri F, Medica M, Gabelli M, Venturini PL, Ferrero S. Outpatient periurethral injections of polyacrylamide hydrogel for the treatment of female stress urinary incontinence: effectiveness and safety. Arch Gynecol Obstet. 2013;288 (1):131-137. doi:10.1007/s00404-013-2718-y

35. Sokol ER, Karram MM, Dmochowski R. Efficacy and safety of polyacrylamide hydrogel for the treatment of female stress incontinence: a randomized, prospective, multicenter North American study. J Urol. 2014;192(3):843-849. doi:10.1016/j.juro.2014.03.109

36. Zivanovic I, Rautenberg O, Lobodasch K, von Bünau G, Walser C, Viereck V. Urethral bulking for recurrent stress urinary incontinence after midurethral sling failure. Neurourol Urodyn. 2017;36(3):722726. doi: $10.1002 /$ nau. 23007

37. Krhut J, Martan A, Jurakova M, Nemec D, Masata J, Zvara P. Treatment of stress urinary incontinence using polyacrylamide hydrogel in women after radiotherapy: 1-year follow-up. Int Urogynecol J. 2016;27(2):301-305. doi:10.1007/s00192-015-2834-2

38. Toozs-Hobson P, Al-Singary W, Fynes M, Tegerstedt G, Lose G. Two-year follow-up of an open-label multicenter study of polyacrylamide hydrogel $\left(\right.$ Bulkamid $^{\mathbb{R}}$ ) for female stress and stress-predominant mixed incontinence. Int Urogynecol J. 2012;23(10):1373-1378. doi:10.1007/s00192-012-1761-8
39. Pai A, Al-Singary W. Durability, safety and efficacy of polyacrylamide hydrogel (Bulkamid ${ }^{\circledR}$ ) in the management of stress and mixed urinary incontinence: three year follow up outcomes. Cent Eur J Urol. 2015;68(4):428-433. doi:10.5173/ceju.2015.647

40. Mouritsen L, Lose G, Møller-Bek K. Long-term follow-up after urethral injection with polyacrylamide hydrogel for female stress incontinence. Acta Obstet Gynecol Scand. 2014;93(2):209-212. doi:10.1111/aogs. 12283

41. Gopinath D, Smith AR, Reid FM. Periurethral abscess following polyacrylamide hydrogel (Bulkamid) for stress urinary incontinence. Int Urogynecol J. 2012;23(11):1645-1648. doi:10.1007/s00192-012-1768-1

42. Freitas A-M, Mentula M, Rahkola-Soisalo P, Tulokas S, Mikkola T. Tension-free vaginal tape versus polyacrylamide hydrogel-injection for primary stress urinary incontinence: a randomized clinical trial. $J$ Urol. 2019;201(4S):e65, abstract PD02-08. doi:10.1097/01.JU.00 $00555032.57705 . \mathrm{bd}$

43. Islam M, Wadhwa H, Dobbs R, Kocjancic E. Management of complications in use of urethral bulking agents in women for stress urinary incontinence - a meta-analysis. J Urol. 2015;193(4S): abstractPD28-04:e645. doi:10.1016/j.juro.2015.02.1901

44. De Vries AM, Wadhwa H, Huang J, Farag F, Heesakkers JPFA, Kocjancic E. Complications of urethral bulking agents for stress urinary incontinence: an extensive review including case reports. Female Pelvic Med Reconstr Surg. 2018;24(6):392-398. doi:10.1097/SPV.0000000000000495

45. Lee PE, Kung RC, Drutz HP. Periurethral autologous fat injection as treatment for female stress urinary incontinence: a randomized double-blind controlled trial. J Urol. 2001;165(1):153-158. doi:10.1097/ 00005392-200101000-00037

46. Lightner D, Rovner E, Corcos J, et al. Randomized controlled multisite trial of injected bulking agents for women with intrinsic sphincter deficiency: mid-urethral injection of Zuidex via the Implacer versus proximal urethral injection of Contigen cystoscopically. Urology. 2009;74(4):771-775. doi:10.1016/j.urology.2009.05.034

47. Hurtado E, McCrery R, Appell R. The safety and efficacy of ethylene vinyl alcohol copolymer as an intra-urethral bulking agent in women with intrinsic urethral deficiency. Int Urogynecol J Pelvic Floor Dysfunct. 2007;18(8):869-873. doi:10.1007/s00192-006-0251-2

48. Capobianco G, Azzena A, Saderi L, Dessole F, Dessole S. Urolastic ${ }^{\circledR}$, a new bulking agent for treatment of stress urinary incontinence: a systematic review and meta-analysis. Int Urogynecol J. 2018;9 (9):1239-1247. doi:10.1007/s00192-018-3703-6

49. de Vries AM, van Breda HMK, Fernandes JG, Venema PL, Heesakkers JPFA. Para-urethral injections with Urolastic ${ }^{\circledR}$ for treatment of female stress urinary incontinence: subjective improvement and safety. Urol Int. 2017;99(1):91-97. doi:10.1159/000452450

50. Radley SC, Chapple CR, Lee JA. Transurethral implantation of silicone polymer for stress incontinence: evaluation of a porcine model and mechanism of action in vivo. BJUInt. 2000;85(6):646650. doi:10.1046/j.1464-410x.2000.00515.x

51. Vasconcelos SJ, Leão RA, Bernardino-Araújo S, Lira MM, Tsuji DH. Effect of sugarcane biopolymer in vocal fold of rabbits. Comparative study with calcium hydroxyapatite. Acta Cir Bras. 2015;30(3):186193. doi:10.1590/S0102-865020150030000004 


\section{Publish your work in this journal}

Research and Reports in Urology is an international, peer-reviewed, open access journal publishing original research, reports, editorials, reviews and commentaries on all aspects of adult and pediatric urology in the clinic and laboratory including the following topics: Pathology, pathophysiology of urological disease; Investigation and treatment of urological disease; Pharmacology of drugs used for the treatment of urological disease. The manuscript management system is completely online and includes a very quick and fair peer-review system, which is all easy to use. Visit http://www.dovepress.com/ testimonials.php to read real quotes from published authors.

Submit your manuscript here: https://www.dovepress.com/research-and-reports-in-urology-journal 